\title{
In Search of the Unknown: Introduction to the Special Issue
}

\author{
René van der Veer
}

Published online: 28 May 2011

(C) The Author(s) 2011. This article is published with open access at Springerlink.com

\begin{abstract}
The problem of aesthetic perception occupied Vygotsky throughout his life. Working in different research collectives or networks he worked out different answers but never reached a final solution. Inadequate and incomplete access to his writings unfortunately hinders us from understanding Vygotsky's ideas and his personal motives. Publication of his notebooks and unadulterated versions of his writings plus an analysis of his research networks will deepen our understanding.
\end{abstract}

Keywords Vygotsky·History of psychology · Aesthetics · Psychology of art

In the latter half of the 1920s Lev Vygotsky (1927, 1928; cf. Fróis 2011) published a paper on contemporary psychology and art in the journal Soviet Art. The theme of Vygotsky's paper was what makes art into art and, as usual, he rejected all existing theories about this topic, in this case because their definitions of art couldn't distinguish between art and non-art. Art cannot just be the transmission of feelings from the artist to the perceiver, as Tolstoy had argued, because many more things outside art evoke emotions as well. Art cannot be reduced to the sublimation of sexual energy, because very many cultural phenomena outside art rest on the sublimation of sexual energy as well, if we may believe psychoanalysis. And the perception of form, which the formalist Shklovsky had claimed was essential in the aesthetic experience, also lacks specificity. For it fails to answer the question what makes one form more aesthetic than another. As Vygotsky (1928, p. 7) concluded: "Verses on sadness lift us above sadness, overcome it, defeat it, solve it. How they achieve this, by what psychological means, that is the $\mathrm{X}$, the proper name of art, the unknown quantity from which any investigation should start” (cf. Fróis 2011).

Vygotsky's little known paper formed part of a long series of writings on the psychology of art that began with his master's thesis on Hamlet (cf. Van der Veer 2007) and ended with his reflections on Stanislavsky's stage directions in the last

R. van der Veer $(\bowtie)$

Department of Education, Leiden University, PO Box 9555, 2300 RB Leiden, The Netherlands e-mail: veer@fsw.leidenuniv.nl 
chapter of Thinking and Speech (Vygotsky 1934). In these writings we can follow Vygotsky's infatuation with literature, art, and theatre and witness how his answers to the question as to what creates an aesthetic effect in the beholder varied with time and with the collectives he formed part of. The youthful master student, inspired by the literary critics Gornfeld and Aikhenwald, claimed that we must preserve the mystery of the work of art, its hidden meaning, which often was not even intended or discovered by the artists themselves, and that each recipient subjectively creates his own very personal version of a book, theatre play, or painting. The $\mathrm{PhD}$ student, who now worked in the environment of reflexologists and reactologists, rejected all subjectivism and argued that the artistic effect is the result of a conflict between form and content created by the artist (cf. Van der Veer 2007). Finally, as we have seen, in 1928, the paedologist working at Moscow University and various other institutes left the question open again. The truly aesthetic effect was created by an unknown quantity, an $x$ that still remained to be discovered. Vygotsky's viewpoints may have fluctuated because his papers were addressed to different audiences and undoubtedly reflected the multiple informal and formal networks of which he formed part in different periods (Yasnitsky, this issue).

Vygotsky's reflections showed a continual theoretical fascination with the problem of aesthetical reception. From the recently discovered notebook (Van der Veer \& Zavershneva, this issue), we now know that this fascination was not just theoretical but deeply personal as well. Vygotsky seems to have had the capacity, or talent, to become deeply moved by a work of art. The paintings by Goya and El Greco overwhelmed him ("My soul is full of flashes of burnt out passions"; Van der Veer \& Zavershneva, this issue) and left him exhausted and in search of an explanation. The same seems to have been true for the other works of art he witnessed ("The soul is lost in the open, enormous and bleak spaces", ibid.). More in general, judging by this notebook, Vygotsky seems to have been a person capable of strong and varying emotions and with an intense need to reflect on these emotions. Here we have a passionate young, newly married man, who was constantly making notes on his most inner feelings, feelings for his wife and daughter, feelings evoked by his being alone in a foreign culture. For whom? Why the obsession to jot down the products of one's inner dialogue during official talks, research meetings, and visits to museums? It was as if Vygotsky needed to externalize his emotions to reflect on them. To make them into text as it were. And that reminds us of a remark made by a contemporary that Vygotsky had no feeling for music at all but could eloquently discuss a piece of music just heard. Perhaps for him, still more than for others, reality could only be experienced and grasped by framing it in language and by commenting and reflecting on that language. Passions had to be overcome by reason. The fact that Vygotsky was a lawyer by training also comes to mind.

Of course, we may never know. But it seems to me that an analysis of Vygotsky's writings on art may provide some key to the motives behind his ideas, to the passions behind the theories, which he himself deemed so important in the last chapter of Thinking and Speech. Against that background, it is a great pity that so little of his literary work is available in English translation and that so many of his writings have come to us in abridged or inadequate form (cf. Van der Veer \& Yasnitsky, this issue). It may take a long time before our present translations are cleansed from the patina of time and censorship. For that reason as well, the title of 
this introduction may be read in several ways: to express that Vygotsky was constantly in search for the unknown $\mathrm{x}$ that would explain psychological phenomena. But also to express that Vygotsky himself still eludes us and that he is an as yet unknown person we seek to understand.

Open Access This article is distributed under the terms of the Creative Commons Attribution Noncommercial License which permits any noncommercial use, distribution, and reproduction in any medium, provided the original author(s) and source are credited.

\section{References}

Fróis, J. P. (2011). Introductory note to "Contemporary psychology and art: Toward a debate" by Lev Vygotsky. Journal of Aesthetic Education, 45, 107-108.

Van der Veer, R. (2007). Lev Vygotsky. London: Continuum.

Vygotsky, L. S. (1927). Sovremennaya psikhologiya i iskusstvo: V poryadke obsuzhdeniya. Sovetskoe Iskusstvo, 3(8), 5-8.

Vygotsky, L. S. (1928). Sovremennaya psikhologiya i iskusstvo: V poryadke obsuzhdeniya. Sovetskoe Iskusstvo, 4(1), 5-7.

Vygotsky, L. S. (1934). Myshlenie i rech: Psikhologicheskie issledovaniya. Moscow-Leningrad: Gosudarstvennoe Sotsiyal'no-Ekomicheskoe Izdatel'stvo.

René van der Veer is Casimir professor of the history of education at Leiden University, The Netherlands. He published widely on the history of developmental psychology and pediatrics. Among his books are Understanding Vygotsky (with Valsiner, 1991), The Social Mind (with Valsiner, 2000), Lev Vygotsky (2007), and Opvoeden door Beginners (2011). 